
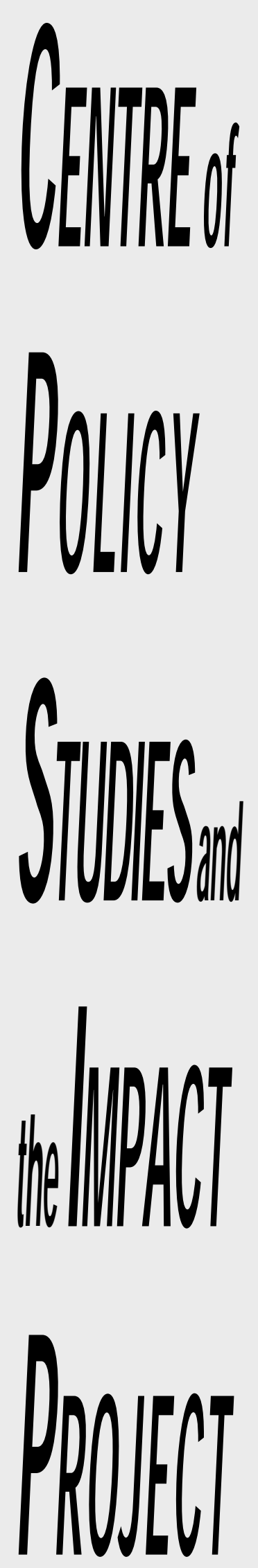

Eleventh Floor

Menzies Building

PO Box 11E, Monash University

Wellington Road

CLAYTON Vic 3800 AUSTRALIA

Telephone:

(03) 9905 2398, (03) 99055112

Fax:

(03) 99052426

e-mail

web site

61399055112 or 61399052398

from overseas:

\section{6}

impact@buseco.monash.edu.au

http://www.monash.edu.au/policy/

\title{
EXPLAINING A DYNAMIC CGE SIMULATION WITH A TRADE-FOCUSED BACK-OF-THE-ENVELOPE ANALYSIS: THE EFFECTS OF ECOMMERCE ON AUSTRALIA
}

by

\section{Peter B. DIXON}

and

\section{Maureen T. RIMMER}

Centre of Policy Studies, Monash University

General Paper G-136, December 2002

The Centre of Policy Studies (COPS) is a research centre at Monash University devoted to quantitative analysis of issues relevant to Australian economic policy. 



\begin{abstract}
This paper was written in honour of Peter J. Lloyd on the occasion of his retirement and celebrates his preeminence as a theorist and practitioner of the economics of international trade.

Besides a surprising number of leading trade theorists, Australia has added significantly to empirical work on trade issues via applied general equilibrium models, especially the ORANI and MONASH models. This paper focuses on one intriguing new topic, namely, the welfare and other economy-wide effects of the development of eCommerce. The direct effects of eCommerce are presented to the Monash model as shocks to 14 sets of technology, preference and trade variables. The shocks were suggested in group discussions with people knowledgeable in the operation of eCommerce and drawn from the sectors most likely to be affected by it.
\end{abstract}

On the conservative assumptions made about the size of the shocks, eCommerce will after about 10 years allow a sustained increase in private and public real consumption of about 3 per cent. This and other results of the MONASH simulation are explained with the help of a relatively simple and small BOTE (back-of-the-envelope) model. 


\section{Contents}

1. Introduction 1

2. The MONASH model and key assumptions in the policy simulation 2 Labour market $\quad 4$

Private expenditure, public expenditure and taxes 5

Rates of return on capital $\quad 5$

Production technologies $\quad 5$

3. The shocks 6

4. Macro results 11

$\begin{array}{ll}\text { 5. Industry and sector results } & 17\end{array}$

6. Results for States, Territories and Statistical Divisions 21

7. Results for Occupations 22

8. The costs of lagging and the benefits of leading 22

9. Concluding remarks 26

Effects of eCommerce $\quad 26$

Trade economists and CGE modelling in Australia 27

References $\quad 29$

\section{Charts}

$\begin{array}{ll}\text { Chart 1. Real GDP and factor inputs } & 12\end{array}$

Chart 2. Contributions to real GDP 12

$\begin{array}{lll}\text { Chart 3. Real investment, consumption and GDP } & 13\end{array}$

Chart 4. Real wage rate, aggregate employment and consumption tax 13

$\begin{array}{lll}\text { Chart 5. Macro trade variables } & 14\end{array}$

$\begin{array}{lll}\text { Chart 6. Output by sector (rank in last year) } & 18\end{array}$

Chart 7. GSPs for States and Territories and GDP for Australia in $2016 \quad 21$

Chart 8. Employment by Statistical Division in 2016

Chart 9. The main winning occupations in 2016

Chart 10. The main losing occupations in $2016 \quad 24$

Chart 11. Consumption in standard, lead and lag simulations 25 


\title{
Explaining a dynamic CGE simulation with a trade-focused back-of-the- envelope analysis: the effects of eCommerce on Australia
}

\author{
by \\ Peter B. Dixon and Maureen T. Rimmer \\ Centre of Policy Studies \\ Monash University
}

\section{Introduction}

This paper was written in honour of Peter Lloyd for presentation on the occasion of his retirement. Together with Arndt, Corden, Gregory, Hazari, Kemp, Salter, Snape, Swan and Woodland, Lloyd is in a select group of economists that have made Australia a leading contributor over the last half century to the development and application of the theory of international trade. ${ }^{1}$

Reflecting the pre-eminence of its trade theorists, Australia's applied multi-sectoral modellers have also emphasised trade issues. The first multi-sectoral model for Australia was the path breaking work of Evans (1972). The Evans model was devoted almost entirely to the analysis of the effects of changes in tariffs. Similarly, protection was the primary focus of Klijn's (1974) model and of the ORANI model [Dixon et al. 1977 and 1982]. While the MONASH model (Dixon and Rimmer, 2002) has a broader range of applications than its predecessors, it retains a strong trade focus.

As measured by the share of trade in its GDP, Australia is not among the world's most tradeoriented nations. This makes the dominance of trade analysis in the work of Australia's theoretical and applied economists somewhat of a surprise. Nevertheless, the concentration on trade has been well justified.

Over many decades Lloyd and Australia's other leading trade economists, supported by multisectoral modellers, have demonstrated the importance to Australia's economic welfare of trade policy.

\footnotetext{
1 For an excellent survey of analysis by Australian economists of trade issues (particularly protection in Australia) see Lloyd (1978).
} 
But the importance of trade policy is not the only justification for their research on trade issues. Since the 1980s it has become apparent from applied multi-sector models that an understanding of the determinants of international commodity and capital flows is essential for the quantification of the effects of almost all economic policies, not just trade policies. Numerous examples can be found of ORANI and MONASH studies showing that the specification of international flows is critical in determining the simulated effects of non-trade-related shocks. A striking example from a recent MONASH study (Dixon and Rimmer, 1999) is the finding that the overall welfare effect of the introduction of the GST is heavily dependent on international tourism. Because tourism services are Australia's only major exports that are subject to the GST, the MONASH simulation showed the tourism sector to be a significant loser. The implication for Australian welfare of GST-induced damage to tourism was then shown to depend on the foreign elasticity of demand for tourism services and on the basecase (no GST) growth forecast for international tourist arrivals.

The remainder of this paper has two objectives. The first is to provide an illustration of the importance of trade flows in the determination of the outcomes for Australia of shocks that are not directly related to trade. The example we have chosen is a MONASH-based analysis of the effects on Australia of the adoption of eCommerce. ${ }^{2}$ The second is to demonstrate that the macro results from detailed models such as MONASH can be understood from back-of-the-envelope (BOTE) calculations with equations that are familiar from simple models used by trade theorists. Once the macro results are understood from these BOTE calculations, the justification of results for industries, occupations and regions becomes straight-forward.

The paper is organized as follows. Section 2 gives a brief overview of the MONASH model. Section 3 lists the shocks that we have used to represent the adoption of eCommerce. Section 4 provides BOTE explanations of the macro results. Sections 5, 6 and 7 discuss the results for industries, regions and occupations. Section 8 looks at the sensitivity of the results to changes in the assumed rate at which eCommerce is adopted. Section 9 contains concluding remarks.

\section{The MONASH model and key assumptions in the policy simulation}

MONASH is a dynamic computable general equilibrium (CGE) model of the Australian economy. In standard applications, it is run with 112 industries. Via a suite of add-on programs, results can be generated for 57 sub-national regions (statistical divisions), 340 occupations and numerous types of households.

2 Our work on eCommerce was originally performed for the National Office for the Information Economy (NOIE). Non-technical descriptions of MONASH eCommerce results prepared by the Allen Consulting Group can be found in NOIE (2000a \& b and 2001). 
MONASH has evolved over the last twenty years from the comparative static ORANI model. Apart from the introduction of dynamics, the main advances in MONASH are associated with closures (choice of exogenous variables). With different closures MONASH produces: estimates of changes in technologies and consumer preferences (historical closure); explanations of historical developments such as the rapid growth since the mid-1980s in Australia's international trade (decomposition closure); forecasts for industries, regions, occupations and households (forecast closure); and projections of the deviations from forecast paths that would be caused by the implementation of proposed policies and by other shocks to the economic environment (policy closure). The results to be described later in this paper were generated by two MONASH simulations, one with a forecast closure and the other with a policy closure.

In forecast closures, we exogenize a wide variety of naturally endogenous variables for which forecast are available from specialist groups. For example, we exogenize most macro variables and shock them with forecasts produced by macro forecasters such as Access Economics, and we exogenize export prices and quantities and shock them with forecasts produced by the Australian Bureau of Agricultural and Resource Economics and by the Bureau of Tourism Research. Exogenization of these naturally endogenous variables requires corresponding endogenizations of naturally exogenous variables such as propensities to consume, invest and import, and the positions of export demand and supply curves. By using specialist forecasts we ensure that MONASH produces credible results, that is results that are consistent with expert opinion. MONASH forecasts are also informed by extrapolations of recent trends in industry technologies and consumer preferences. These trends are derived from MONASH historical simulations in which the model is given sufficient freedom in the determination of technology and preference variables to allow it to reproduce historical movements in observable variables such as industry inputs and outputs and consumption by commodity.

In policy closures, naturally endogenous variables such as macro aggregates and export prices and quantities are endogenous. In policy simulations these variables must be endogenous so that they respond to the policy shocks. Naturally exogenous variables such as propensities to consume, invest and import, and the positions of export demand and supply curves are exogenous.

If all of the exogenous variables in a policy simulation are given the values that they had either endogenously or exogenously in the associated forecast simulation, then the policy simulation reproduces the forecast results. However, in policy simulations some of the exogenous variables are given different values from those in the forecast simulation. For example, in our eCommerce analysis, technology and preference variables in the policy simulation are moved away from the historical trend values adopted in the forecast simulation. The imposed deviations in these variables reflect judgements about the direct effects of eCommerce on technology and preferences. The comparison of 
policy results with forecast results then shows the effects of eCommerce on macro, industry, regional and occupational variables as deviations from explicit and realistic forecasts.

The use of realistic forecasts is important in policy analysis for two reasons. First, basecase forecasts of, for example, the relative sizes of industries and the commodity composition of exports affect the simulated values to the economy of shocks such as the adoption of eCommerce. Second, in cases where a policy is likely to cause a reduction in employment in an industry, the basecase forecast is critical in estimating adjustment costs. These costs depend on whether the adjustment will be handled by a reduced rate of hiring or an increased rate of firing.

The details of MONASH policy closures can be varied to introduce different macroeconomic assumptions. The main macro assumptions in the policy simulation (the effects of eCommerce) presented later in this paper are as follows.

\section{Labour market}

We assume that workers are concerned with the real after-tax wage rate, that is, the wage rate less income taxes, deflated by the CPI. If the labour market strengthens, then we assume that the real after-tax wage rate rises in response to increased worker negotiating strength. More precisely, we assume that

$$
\left\{\frac{\mathrm{W}_{\mathrm{t}, \mathrm{p}}}{\mathrm{W}_{\mathrm{t}, \mathrm{f}}}-1\right\}=\left\{\frac{\mathrm{W}_{\mathrm{t}-1, \mathrm{p}}}{\mathrm{W}_{\mathrm{t}-1, \mathrm{f}}}-1\right\}+\alpha\left\{\frac{\mathrm{E}_{\mathrm{t}, \mathrm{p}}}{\mathrm{E}_{\mathrm{t}, \mathrm{f}}}-\frac{\mathrm{LS}_{\mathrm{t}, \mathrm{p}}}{\mathrm{LS}_{\mathrm{t}, \mathrm{f}}}\right\},
$$

where

$\mathrm{W}_{\mathrm{t}, \mathrm{f}}, \mathrm{E}_{\mathrm{t}, \mathrm{f}}$ and $\mathrm{LS}_{\mathrm{t}, \mathrm{f}}$ are the real after-tax wage rate, aggregate employment and the long-run labour supply in year $t$ in the basecase forecast simulation;

$\mathrm{W}_{\mathrm{t}, \mathrm{p}}, \mathrm{E}_{\mathrm{t}, \mathrm{p}}$ and $\mathrm{LS}_{\mathrm{t}, \mathrm{p}}$ are the real after-tax wage rate, aggregate employment and the long-run labour supply in year $t$ in the policy simulation, that is the simulation with the eCommerce shocks; and $\alpha$ is a positive parameter.

Under (2.1), the real after-tax wage rate in a policy simulation moves further above its value in the forecast simulation if the ratio of policy employment to forecast employment is greater than the ratio of policy long-run labour supply to forecast long-run labour supply. Long-run labour supply is specified in MONASH policy simulations as a function of lagged real after-tax wage rates and various shift variables. In the policy simulation reported in this paper, the elasticity of long-run labour supply to lagged real after-tax wage rates is zero. Thus, in the absence of supply shifts, $\operatorname{LS}_{\mathrm{t}, \mathrm{p}} / \mathrm{LS}_{\mathrm{t}, \mathrm{f}}=1$, reducing (2.1) to

$$
\left\{\frac{\mathrm{W}_{\mathrm{t}, \mathrm{p}}}{\mathrm{W}_{\mathrm{t}, \mathrm{f}}}-1\right\}=\left\{\frac{\mathrm{W}_{\mathrm{t}-1, \mathrm{p}}}{\mathrm{W}_{\mathrm{t}-1, \mathrm{f}}}-1\right\}+\alpha\left\{\frac{\mathrm{E}_{\mathrm{t}, \mathrm{p}}}{\mathrm{E}_{\mathrm{t}, \mathrm{f}}}-1\right\} .
$$

Under (2.2), wages rise in policy relative to forecast whenever employment in policy is above its level in forecast. However, as will be apparent in sections 3 and 4, we introduce shifts in long-run labour supply to represent time-saving by households from the use of eCommerce. If these shifts cause a 
deviation in long-run labour supply in year t of $x$ per cent, then under (2.1), the policy induced deviation in the real after-tax wage rate increases in year t relative to year $\mathrm{t}-1$ if and only if the policyinduced deviation in employment in year $\mathrm{t}$ is more than $x$ per cent. While favourable shocks such as the adoption of eCommerce can temporarily produce positive gaps between employment and long-run labour supply, we can expect these gaps to close under (2.1) as wage rates rise thereby reducing labour demand. The rate at which gaps are closed is controlled largely by the parameter $\alpha$. In the policy simulation reported in this paper, the value of $\alpha$ was set so that the short-run gap generated by any shock is substantially eliminated within 5 years of the shock. Our labour market specification can be summarised as short-run real-wage stickiness and long-run real-wage flexibility. It is consistent with conventional macro-economic modelling in which the NAIRU is exogenous.

\section{Private expenditure, public expenditure and taxes}

The shocks considered in this paper (the adoption of eCommerce) generate increases in national income, providing the potential for increases in private and public consumption. Consistent with the emphasis in recent years on small government, we assume that the eCommerce-induced percentage deviations in public consumption are half those in private consumption. For example, if in a particular year eCommerce generates a two per cent increase in real household disposable income, causing private consumption to be two per cent greater than it would otherwise have been, then we assume that public consumption is one per cent greater than it would otherwise have been. As well as adjusting the path of public consumption, we assume that the government adjusts the path of consumption taxes so that the adoption of eCommerce does not affect the path of the public sector deficit.

\section{Rates of return on capital}

In simulations of the effects of changes in policy and other exogenous variables, MONASH allows for short-run divergences in after-tax rates of return on industry capital stocks from their levels in the basecase forecasts. Short-run increases/decreases in rates of return cause increases/decreases in investment and capital stocks, thereby gradually eroding the initial divergences in after-tax rates of return.

\section{Production technologies}

MONASH contains variables describing: primary-factor and intermediate-input-saving technical change in current production; input-saving technical change in capital creation; input-saving technical change in the provision of margin services; and input-saving changes in household 
preferences. $^{3}$ In the policy simulation described in this paper, all of these variables are exogenous. We move a selection of them away from their basecase forecast values to introduce the direct affects of eCommerce on technology and preferences.

\section{The shocks}

In 1999, Kerry Barwise of the Allen Consulting Group (ACG), with sponsorship from the National Office for the Information Economy (NOIE) and several other organizations, chaired a series of meetings for people from business and government who were knowledgeable in the area of eCommerce. The aim of these meetings was to obtain a broad picture of the likely effects of adoption of eCommerce on the conduct of business. Our task was to lead the participants in the meetings towards a quantification of their views in terms of effects on variables describing technologies and preferences. After an iterative process, consisting of qualitative and anecdotal discussion by participants, quantitative suggestions from us and further discussion by participants, an agreed list of shocks to be applied to the MONASH model emerged. ${ }^{4}$

On the assumption that the adoption of eCommerce is a gradual process, we phased in the shocks to MONASH over 10 years, commencing in 1998. We assumed that each shock operates in year 1 (1998) at a tenth of its eventual strength, in year 2 (1999) at two tenths of its eventual strength and in years 10 (2007) and beyond at its full strength. The shocks, organized in 14 sets, are described below. For each set of shocks we provide an estimate of the full-strength direct GDP effect. For example, if a set of shocks saves 10 per cent of an industry's labour and the industry's labour represents 5 per cent of GDP, then the direct GDP effect is 0.5 per cent. This recognizes that the shock releases resources which can be used to generate a 0.5 per cent increase in GDP. We also note for each set of shocks the direct effect on consumption (combined private and public). In most cases this can be considered an indicator of the direct welfare effect of the set of shocks.

\section{(s1) Saving of margins by consumers}

For books we assume that eCommerce will, after 10 years, reduce retail margins by 30 per cent. For most other goods we assume reductions in retail margins of between 0 and 20 per cent. Overall, the average reduction in retail margins is 12.8 . This is a saving to consumers of about $\$ 4.7$ billion in 1996-97 prices, equivalent to about 0.95 per cent of GDP.

\footnotetext{
${ }^{3}$ These variables are the A's in production and utility functions of the form $F\left(X_{1} / A_{1}, \ldots, X_{n} / A_{n}\right)$ where the $X$ 's are quantities of inputs or consumption.

${ }^{4}$ Litan and Rivlin (2001) describe a rather similar process for finding out about the direct effects of eCommerce in the United States. However, they stopped with the direct technology effects. They did not use an economic model to translate these effects into ultimate effects.
} 
Reductions in retail margins are likely to require increases in wholesale margins. Rather than dealing with retailers, consumers will deal more directly with wholesalers. We assume that half the savings of retail margins are lost to consumers via increases in wholesale margins. This is a loss to consumers of about $\$ 2.35$ billion in 1996-97 prices. Together the changes in retail and wholesale margins generate a gain in GDP of about $\$ 2.35$ billion, that is 0.47 per cent of GDP.

All of the GDP gain generated by changes in margins is available for extra private and public consumption. Because private and public consumption are about 80 per cent of GDP, a gain in GDP of 0.47 per cent translates into a consumption gain of 0.60 per cent.

$$
\begin{aligned}
\text { GDP effect } & =0.47 \% \\
\text { Consumption and welfare effects } & =0.60 \%
\end{aligned}
$$

\section{(s2) Saving of time by households}

eCommerce reduces households' non-discretionary shopping time. In our simulation we assume that the time saved could generate labour income of half the net savings generated by the net reduction in consumer margins (the retail and wholesale margins discussed in s1), that is we assume there is a potential increase in labour supply worth $\$ 1.17$ billion in $1996-97$ prices $(=2.35 / 2)$. Of this potential increase in labour supply, we assume that half ( $\$ 0.59$ billion) is translated into extra leisure and half into extra labour supply. This represents an increase in labour supply of about 0.20 per cent, generating an increase in GDP of about 0.12 per cent and a corresponding increase in private and public consumption of 0.15 per cent $(=0.12 / 0.8)$. In calculating welfare we include the increase in leisure. Thus the welfare effect is equivalent to an increase in consumption of 0.30 per cent.

$$
\begin{aligned}
\text { GDP effect } & =0.12 \% \\
\text { Consumption effect } & =0.15 \% \\
\text { Welfare effect } & =0.30 \%
\end{aligned}
$$

\section{(s3) Purchase of eCommerce equipment and services by households}

We assume that households purchase eCommerce equipment and services worth 25 per cent of consumer-margin cost savings $(\$ 2.35 \mathrm{~b}, \mathrm{~s} 1)$. That is, consumers in year 10 purchase equipment and services worth $\$ 0.59$ billion. We simulate this as a change in consumer preferences requiring extra expenditures on: (a) electronic equipment of $\$ 0.059$ billion; (b) communications of $\$ 0.059$ billion; (c) Banking of $\$ 0.247$ billion; (d) non-bank finance of $\$ 0.165$ billion; and (e) business services of $\$ 0.059$ billion.

Changes in consumer preferences have no direct effect on GDP. For welfare analysis we recognize that purchase of eCommerce equipment and services is an expense to consumers not a benefit. 


\section{(s4) Saving of margins by industries}

For most inputs to industries we assume that eCommerce will reduce wholesale and retail margins by 5 per cent over 10 years. For consumer goods used as inputs to industries we assume that margins savings will be at the same rate as for households (s1). Under these assumptions the overall reduction in margins on inputs to industries is about $\$ 1.85$ billion, approximately 5 per cent of wholesale and retail margins on inputs to current production and capital creation. This saving of margins in business translates to a direct GDP gain of about 0.37 per cent.

$$
\begin{aligned}
\text { GDP effect } & =0.37 \% \\
\text { Consumption and welfare effect } & =0.46 \%
\end{aligned}
$$

\section{(s5) Saving of labour by industries in buying inputs}

eCommerce will reduce shopping time not only for households but also for firms. We simulate this as a labour-saving technical change worth half the savings of margins by industries, that is half of effect (s4).

$$
\begin{aligned}
\text { GDP effect } & =0.19 \% \\
\text { Consumption and welfare effect } & =0.23 \%
\end{aligned}
$$

\section{(s6) Purchases of eCommerce equipment by industries}

As with households, we assume that industries must buy eCommerce equipment and services worth 25 per cent of their margins savings (s4). By the tenth year this is an annual cost to the economy of about 0.093 per cent of GDP.

$$
\begin{aligned}
\text { GDP effect } & =-0.09 \% \\
\text { Consumption and welfare effect } & =-0.12 \%
\end{aligned}
$$

\section{(s7) Direct labour saving technical progress in transport and banking}

We assume that over the period 1998 to 2007 eCommerce will reduce labour costs by 5 per cent in the Transport and Banking sectors (MONASH industries 93, 96, 97, 99 and 100). ${ }^{5}$ These cost savings will arise from reductions in staff required to provide services to the public, e.g. selling airline tickets.

$$
\begin{array}{r}
\text { GDP effect }=0.28 \% \\
\text { Consumption and welfare effect }=0.35 \%
\end{array}
$$

(s8) Time-saving by industries dealing with the transport and banking sectors

If industry $\mathrm{j}$, where $\mathrm{j}$ is any industry except Ownership of dwellings (104), uses 10 per cent of the services sold by the Banking sector (industries $99 \& 100$ ), then we assume that industry $\mathrm{j}$ makes labour savings worth half of 10 per cent of the savings made by Banking. A similar treatment is

\footnotetext{
5 The MONASH industry and commodity categories used in the present study can be seen in NOIE (2000a,
} Tables A3 and A1). 
adopted with respect to industry purchases of services from the Transport sector (industries $93,96 \&$ 97).

$$
\begin{aligned}
G D P \text { effect } & =0.06 \% \\
\text { Consumption and welfare effect } & =0.08 \%
\end{aligned}
$$

(s9) Time-saving by households dealing with the transport and banking sectors

If households use 10 per cent of the services sold by industry $q(q=93,96,97,99$ and 100) then we assume that households save time worth half of 10 per cent of the direct savings made by industry q. We also assume that if Ownership of dwellings uses 10 per cent of the services sold by industry $q(q=93,96,97,99$ and 100) then households receive a time saving worth half of 10 per cent of the savings made by industry q. We assume that half of the time-saving made by households is devoted to labour and half is devoted to leisure.

$$
\begin{array}{r}
\text { GDP effect }=0.01 \% \\
\text { Consumption effect }=0.02 \% \\
\text { welfare effect }=0.04 \%
\end{array}
$$

\section{(s10) Additional margins savings by the Communications industry (98)}

As well as the margin savings outlined in $\mathrm{s} 4$, we assume that the Communications industry will save an additional 20 per cent of the wholesale margins on all its purchases. The Communication industry's participants in the NOIE-sponsored meetings felt that eCommerce will be particularly important in enabling the Communications industry to buy directly from producers.

GDP effect $=0.05 \%$ Consumption and welfare effect $=0.06 \%$

\section{(s11) Saving of particular inputs}

We assume that the Banking sector (industries $99 \& 100$ ) will save 5 per cent of its inputs of paper products (commodities 49 and 50).

$$
\begin{aligned}
\text { GDP effect } & =0.01 \% \\
\text { Consumption and welfare effect } & =0.02 \%
\end{aligned}
$$

We assume that Business services (industry 103) will save 5 per cent of its inputs of paper (commodities $49 \& 50$ ), machinery and equipment (commodities 74 to 80 ) and financial and business services (commodities 101 to 105 ).

$$
\begin{aligned}
G D P \text { effect } & =0.12 \% \\
\text { Consumption and welfare effect } & =0.15 \%
\end{aligned}
$$

We assume that the Banking industry (99) will save 3 per cent of the costs of construction inputs to capital creation. eCommerce will reduce the need for constructing branch offices. 


\section{(s12) Twist in favour of imports}

eCommerce will increase awareness by Australian households and industries of foreign products. We represent this by a twist in preferences which at given prices increases the ratio of imports to purchases of domestic products by 5 per cent.

\section{GDP effect $=0.00 \%$ \\ Consumption and welfare effect $=0.00 \%$}

\section{(s13) Increase in foreign awareness of Australian products}

eCommerce will increase foreign awareness of many of Australia's manufactured commodities and of tourism opportunities in Australia. For most MONASH manufactured commodities (25 - 48, $53-57,59-85,101-105)$ and for tourism we assume a vertical upward movement in foreign demand curves of 5 per cent. For commodities 49 and 50 (publishing and printing) we assume an upward movement of 10 per cent. For agricultural, mineral and standard processed food products, we assume movements of zero per cent. For these traditional export commodities, it seems likely that foreign awareness will not be increased by eCommerce.

Combined, the shifts in export demand curves have an impact effect on the terms of trade of 2.4 per cent. With exports representing about 20 per cent of GDP, this terms-of-trade improvement is equivalent to a gift to consumers worth about 0.60 per cent $(=0.2 * 2.4 / 0.8)$ of private and public consumption.

\section{GDP effect $=0.00 \%$ \\ Consumption and welfare effect $=0.60 \%$}

\section{(s14) Reductions in foreign-currency c.i.f. prices of imports}

Sophisticated eCommerce in Australia will help Australian households get a better deal on imported products. We recognize this by assuming for most commodities that households will be able to save foreign margins worth 50 per cent of the margins that they save in Australia. For example, if we assume that saving of Australian margins reduces the price of clothing in Australia by 1 per cent, then we assume that shopping around using eCommerce reduces c.i.f prices of imported clothes by 0.5 per cent. Participants in the NOIE-sponsored meetings felt that the import prices of books and commercial printing (commodities 49 and 50) are particularly susceptible to shopping around. For these commodities we assume that the percentage reductions in c.i.f. prices are equal to the percentage reductions in Australian prices caused by savings of Australian margins.

After 10 years the assumed reduction in average import prices caused by Australia's adoption of eCommerce is 0.76 per cent. With imports being about 25 per cent as large as private and public consumption, the reduction in import prices of 0.76 per cent has an impact effect on consumption of 0.19 per cent. 


\section{Aggregate effects}

Adding over the 14 sets of shocks we obtain:

$$
\begin{aligned}
\text { GDP effect } & =1.60 \% \\
\text { Consumption effect } & =2.80 \% \\
\text { welfare effect } & =2.82 \%
\end{aligned}
$$

The GDP effect consists of a 1.47 per cent increase from technological improvements and a 0.13 per cent increase from additional labour supply.

\section{Macro results}

Charts 1 to 5 contain macro results from the MONASH model for the effects of the 14 sets of shocks listed in section 3. The charts show percentage deviations from the basecase forecasts. For example, chart 1 implies that in 2007 real GDP will be 2.7 per cent higher if Australia embraces eCommerce (that is, experiences the 14 sets of shocks) than if it doesn't.

We explain the MONASH macro results via a trade-focused BOTE model in which Australia produces and exports grain (good g), imports vehicles (good v),consumes g and v and creates capital from $g$ and $\mathrm{v}$.

The production function for good $\mathrm{g}$ is of the form

$$
\mathrm{Y}=\mathrm{A} * \mathrm{~F}(\mathrm{~K}, \mathrm{~L})
$$

where

$\mathrm{Y}$ is output of grain;

$\mathrm{K}$ and $\mathrm{L}$ are inputs of capital and labour;

$\mathrm{F}$ is a homogeneous function of degree one (constant returns to scale); and

$\mathrm{A}$ is a technology variable, with increases in A representing technological improvements.

Assuming that factors are paid the values of their marginal products, we obtain

$$
\begin{aligned}
& \mathrm{W}=\mathrm{P}_{\mathrm{g}} * \mathrm{~A} * \mathrm{~F}_{l} \\
& \mathrm{Q}=\mathrm{P}_{\mathrm{g}} * \mathrm{~A} * \mathrm{~F}_{\mathrm{k}}
\end{aligned}
$$

where

$\mathrm{W}$ is the wage rate;

$\mathrm{P}_{\mathrm{g}}$ is the price of grain;

$\mathrm{Q}$ is the rental rate on capital; and

$\mathrm{F}_{\mathrm{k}}$ and $\mathrm{F}_{l}$ are the first derivatives of $\mathrm{F}$.

$\mathrm{F}_{\mathrm{k}}$ is a decreasing function of $\mathrm{K} / \mathrm{L}$ and $\mathrm{F}_{l}$ is an increasing function of $\mathrm{K} / \mathrm{L}$.

Next, we define the price deflators $\left(\mathrm{P}_{\mathrm{c}}\right.$ and $\left.\mathrm{P}_{\mathrm{i}}\right)$ for consumption and investment by

$$
\begin{aligned}
& \mathrm{P}_{\mathrm{c}}=\mathrm{P}_{\mathrm{g}}^{\gamma} * \mathrm{P}_{\mathrm{v}}^{(1-\gamma) * \mathrm{~T}_{\mathrm{c}}} \\
& \mathrm{P}_{\mathrm{i}}=\mathrm{P}_{\mathrm{g}}^{\delta} * \mathrm{P}_{\mathrm{v}}^{(1-\delta)}
\end{aligned}
$$

where 
Chart 1. Real GDP and factor inputs

(\% deviation from basecase forecasts)

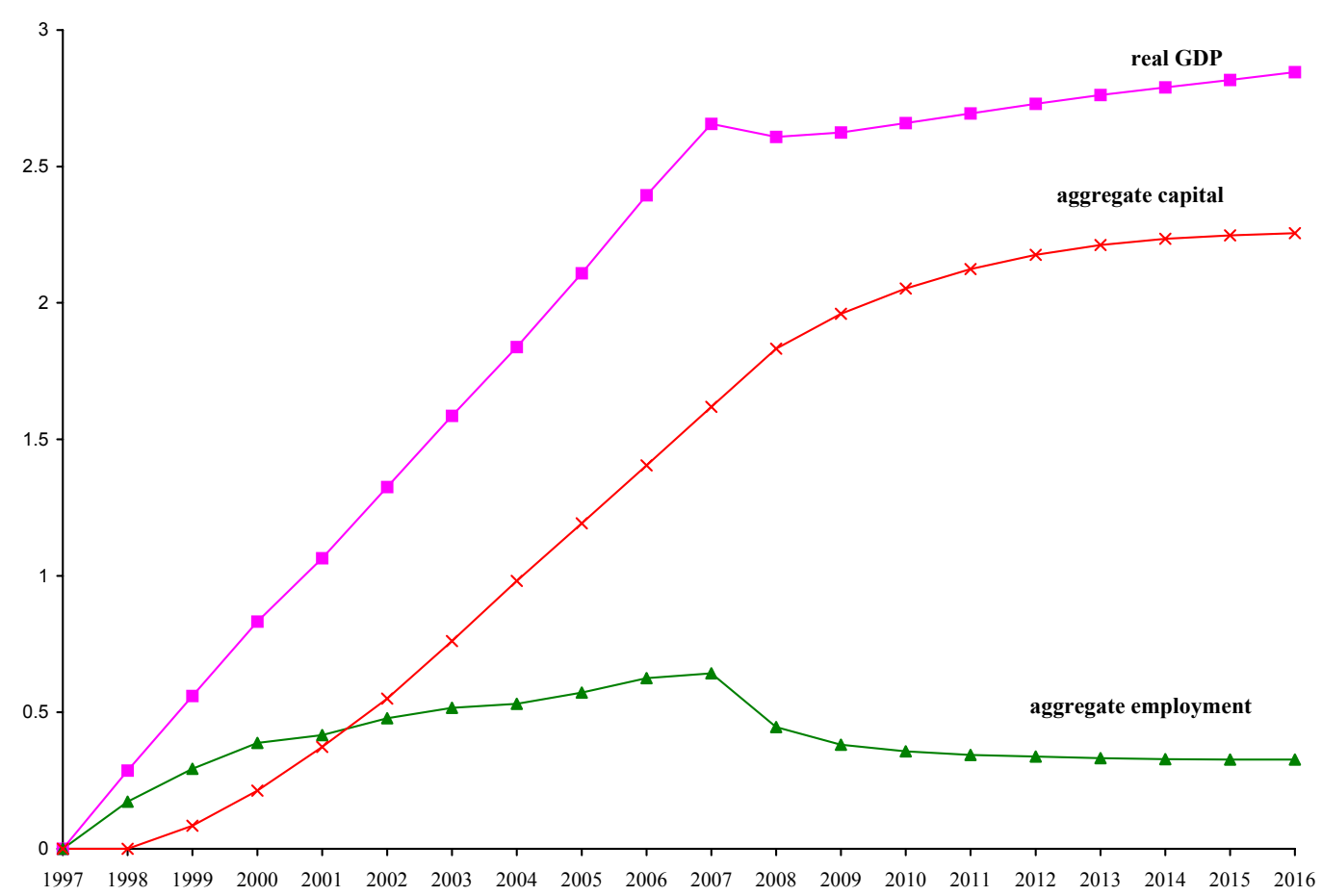

Chart 2. Contributions to real GDP

( $\%$ deviation from basecase forecasts)

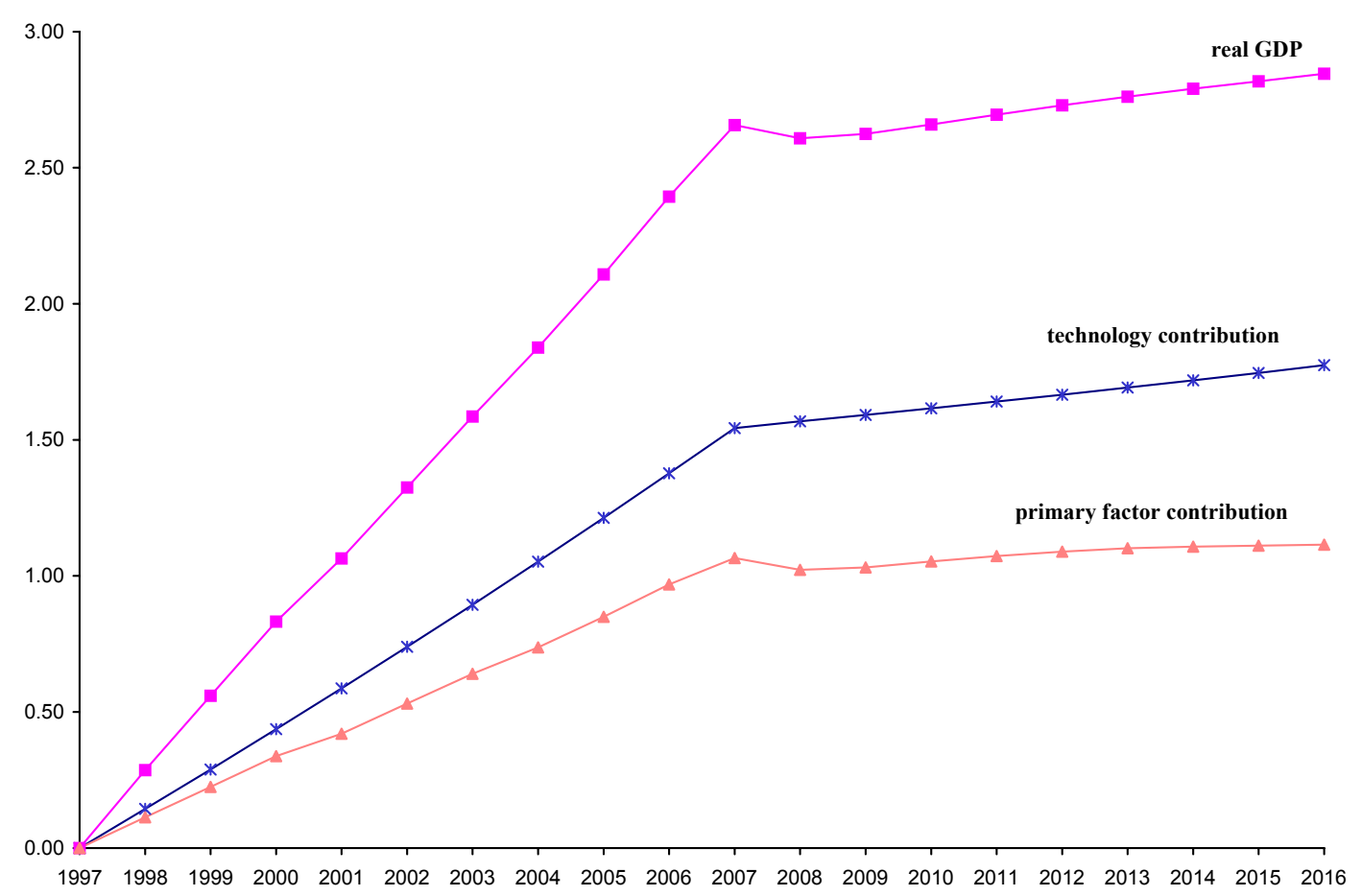


Chart 3. Real investment, consumption and GDP

( $\%$ deviation from basecase forecasts)

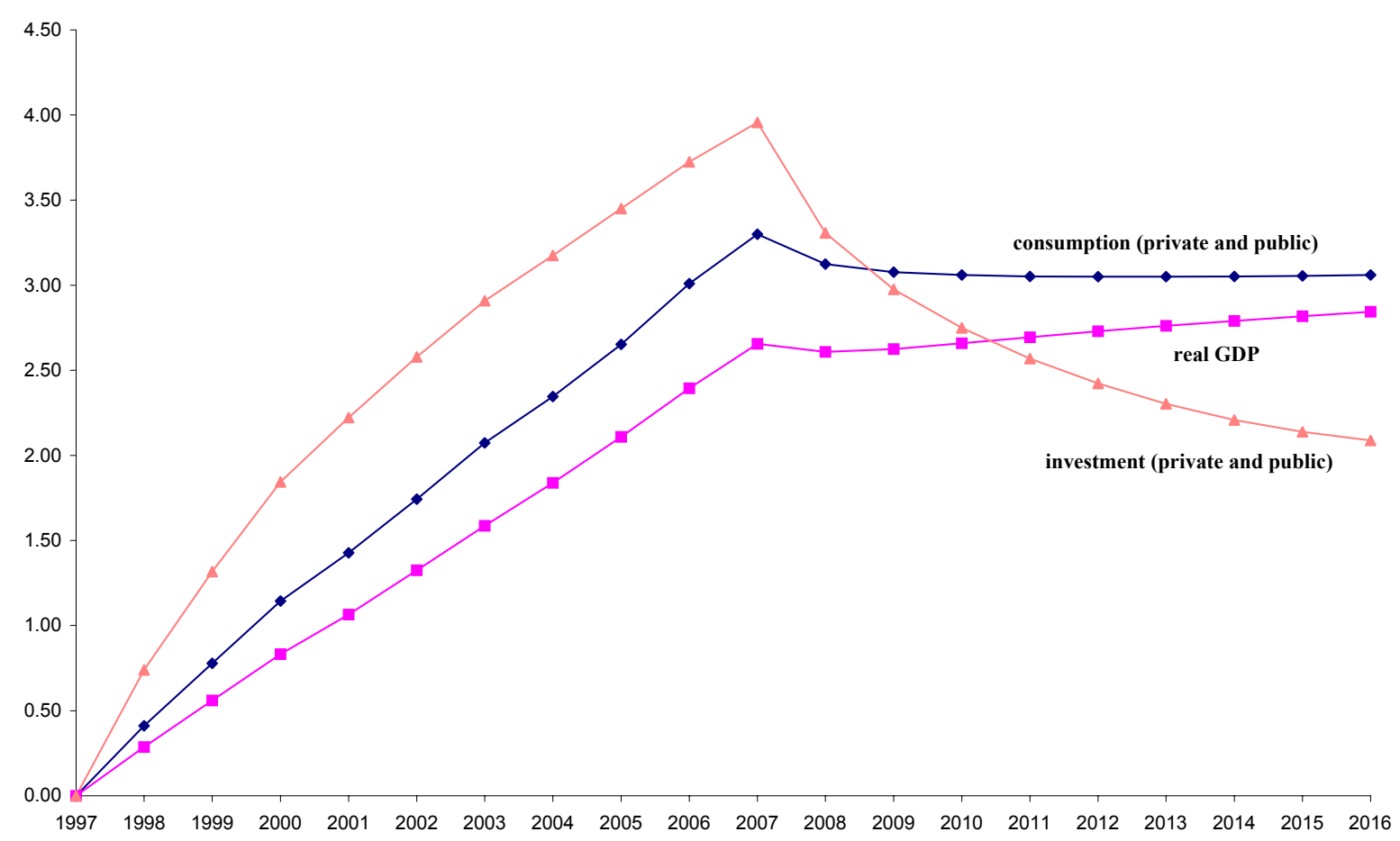

Chart 4. Real wage rate, aggregate employment and consumption tax (\% deviation from basecase forecasts)

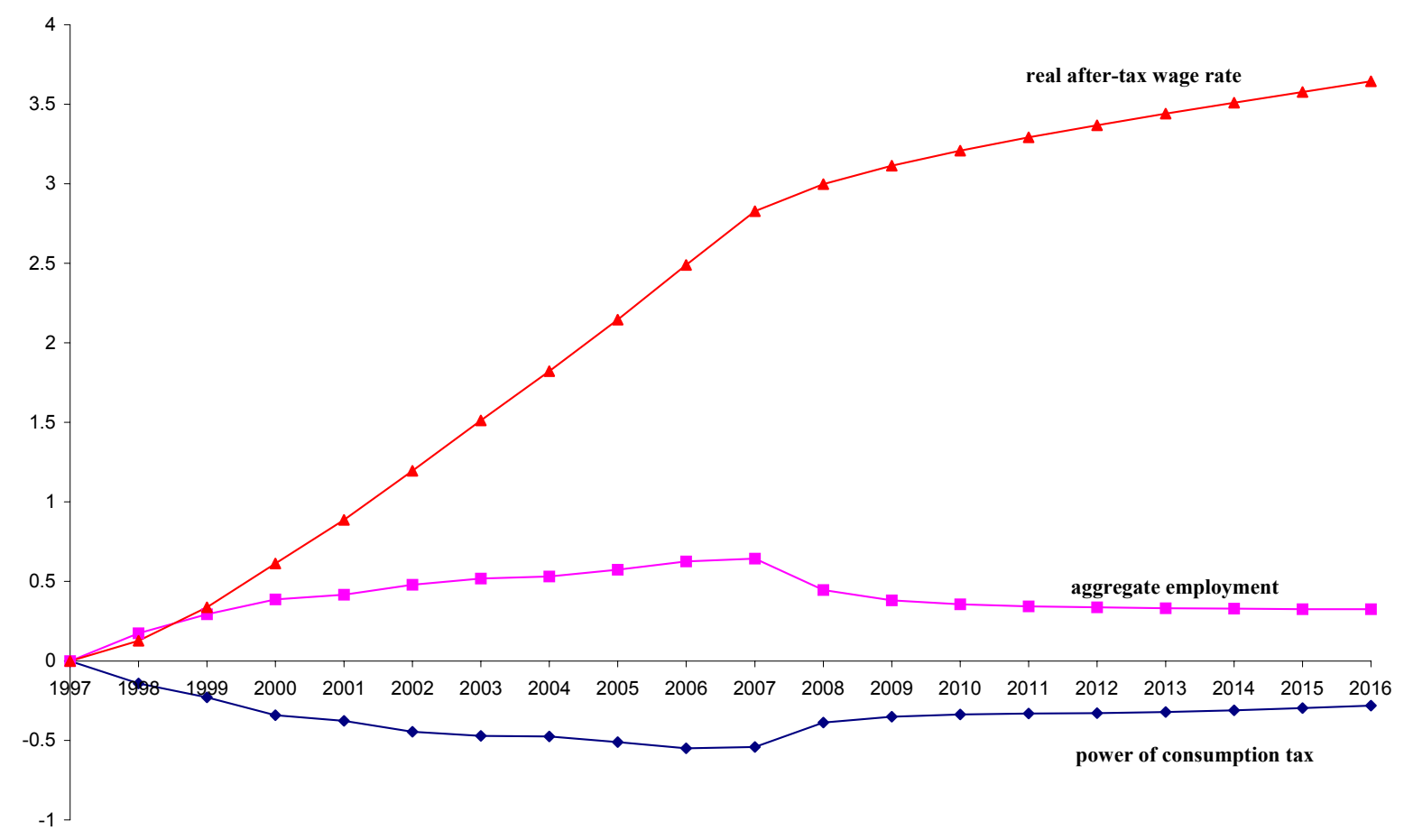


Chart 5. Macro trade variables

(\% deviation from basecase forecasts)

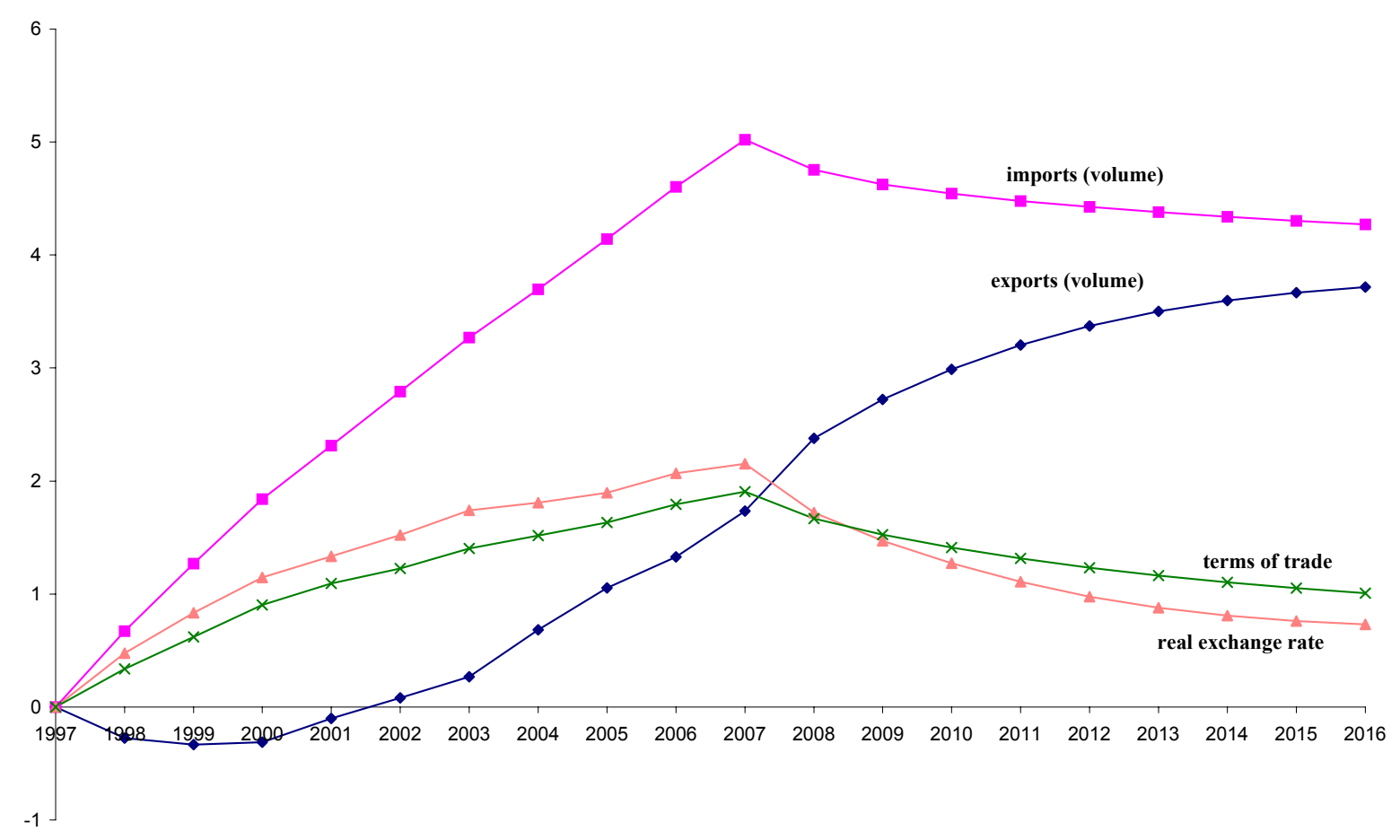

$\mathrm{P}_{\mathrm{v}}$ is the price of vehicles;

$\mathrm{T}_{\mathrm{c}}$ is the power $(1+$ rate $)$ of the tax on consumption; and $\gamma$ and $\delta$ are positive parameters reflecting the share of grain in consumption and investment.

From (4.2) to (4.5) we find that

$$
\mathrm{W}_{\mathrm{r}}=\frac{1}{\mathrm{~T}_{\mathrm{c}}} *\left(\frac{\mathrm{P}_{\mathrm{g}}}{\mathrm{P}_{\mathrm{v}}}\right)^{(1-\gamma)} * \mathrm{~A} * \mathrm{~F}_{l}
$$

and

$$
\mathrm{R}=\left(\frac{\mathrm{P}_{\mathrm{g}}}{\mathrm{P}_{\mathrm{v}}}\right)^{(1-\delta)} * \mathrm{~A} * \mathrm{~F}_{\mathrm{k}}
$$

where

$\mathrm{W}_{\mathrm{r}}$ is the real wage rate defined as $\mathrm{W} / \mathrm{P}_{\mathrm{c}}$; and

$\mathrm{R}$ is the rate of return on capital defined as the ratio of the rental price of capital $(\mathrm{Q})$ to the asset price of capital $\left(\mathrm{P}_{\mathrm{i}}\right)$.

Our simulation of the effects of eCommerce involves increases in $\mathrm{A}, \mathrm{L}$ and the terms of trade $\left(\mathrm{P}_{\mathrm{g}} / \mathrm{P}_{\mathrm{v}}\right)$. In the long run, we expect rates of return in Australia to be unaffected by eCommerce. Thus via (4.7) we see that $F_{k}$ must decline and $K / L$ must increase. The increase in $K / L$ can be seen in chart 1 where the long-run increase in $\mathrm{K}$ is about 2.26 per cent and the long-run increase in $\mathrm{L}$ is only about 0.33 per cent. 
Most ( 0.22 per cent) of the long-run increase in $\mathrm{L}$ arises from time-saving by households [shocks (s2) and (s9)]. The rest is explained by the relationship between the eCommerce shocks and the basecase forecasts. Beyond 2007, there are no further eCommerce shocks to individual technology variables or to foreign demand curves. Nevertheless, there are continuing increases in the aggregate eCommerce-induced improvement in technology and in the aggregate upward shift in foreign demand curves for Australian products. This is for two reasons. First, the eCommerce shocks produce technological improvements concentrated in parts of the economy (e.g. banking) that are fast growing in our basecase forecasts. Second, the eCommerce-induced upward shifts in foreign-demand curves are concentrated in export markets (e.g. tourism) that are fast growing in our basecase forecasts. In terms of our BOTE model it is as though $\mathrm{A}$ and $\mathrm{P}_{\mathrm{g}} / \mathrm{P}_{\mathrm{c}}$ continue to receive positive shocks throughout the simulation period. This allows the employment deviation ( 0.33 per cent) to settle above the longrun supply deviation ( 0.22 per cent), despite continuing increases in $\mathrm{W}_{\mathrm{r}}$.

In MONASH, investors are modelled as responding cautiously to good news. Thus the movement to a higher value for $\mathrm{K} / \mathrm{L}$ is gradual. It is achieved over and beyond the ten year period of favourable shocks from eCommerce adoption. In chart 3 the deviation in investment increases for all of the ten years of eCommerce shocks and then tapers off. In year one, investment is responding to the favourable shock in year 1; in year 2, investment is responding to the favourable shock in year 2 and continuing its response to the favourable shock in year 1; in year 10 investment is responding to the favourable shock in year 10 and continuing its response to the favourable shocks in previous years; in year 11 and subsequent years there are no further favourable shocks and investment is gradually completing its responses to the favourable shocks of years 1 to 10 .

Increases in $\mathrm{A}, \mathrm{K}$ and $\mathrm{L}$ generate an increase in $\mathrm{Y}$ via (4.1). In percentage change terms, (4.1) can be written as:

$$
\mathrm{y}=\mathrm{a}+\mathrm{S}_{\mathrm{k}} * \mathrm{k}+\mathrm{S}_{I} * I
$$

where

$\mathrm{y}, \mathrm{a}, \mathrm{k}$ and $l$ are the percentage deviations in $\mathrm{Y}, \mathrm{A}, \mathrm{K}$ and $\mathrm{L}$ caused by eCommerce; and

$\mathrm{S}_{\mathrm{k}}$ and $\mathrm{S}_{l}$ are the shares of $\mathrm{K}$ and L in GDP (approximately 0.4 and 0.6 ).

The shocks listed in section 3 imply an increase in A of about 1.5 per cent. With the long-run increases in $\mathrm{K}$ and $\mathrm{L}$ being 2.26 and 0.33 per cent, equation (4.8) gives

$$
\mathrm{y}=1.5+0.4 * 2.26+0.6 * 0.33=2.60 \quad
$$

This is close to the long-run increase in GDP shown in chart 1. Chart 2 uses (4.8) to disaggregate the percentage deviations in GDP into the technology contribution (the increase in A) and the primary factor contribution (the weighted average of the increases in $\mathrm{K}$ and $\mathrm{L}$ ). The contribution of technology continues to increase beyond the shock period because, as explained earlier, the eCommerce 
technology shocks are concentrated in parts of the economy showing fast growth in the basecase forecast.

With an increase in $\mathrm{K} / \mathrm{L}$, there is an increase in $\mathrm{F}_{l}$. This, together with the increases in $\mathrm{P}_{\mathrm{g}} / \mathrm{P}_{\mathrm{v}}$ and A, produces a strong increase in the real wage rate [see (4.6) and chart 4]. The increase in the real wage rate is reinforced by a cut in consumption taxes $\left(T_{c}\right.$, chart 4$)$. As mentioned in section 2, we assume that consumption taxes adjust to stabilize the public sector budget. The fall in consumption taxes reflects reductions in unemployment benefits and our assumption that the eCommerce-induced percentage expansion in public consumption is half that of private consumption. The cut in consumption taxes is preserved into the long run but is reduced beyond 2007 as the employment deviation falls towards its eventual long-run level. Employment in the short run overshoots its longrun level because of sticky adjustment in real wages to the shocks during the period 1998 to 2007.

The deviation path for private and public consumption (chart 3 ) lies above that for GDP but has approximately the same shape. The gap between the consumption and GDP paths is mainly a reflection of the improvement in the terms of trade which allows increased consumption independently of increases in output. In the long run, the eCommerce-induced increase in private and public consumption is about 3 per cent. Four factors contribute to this increase:

- the long-run increase in employment of 0.33 per cent. This produces additional GDP of 0.2 per cent $\left(=0.33^{*} .6\right)$ allowing an increase in private and public consumption of 0.25 per cent $(=0.2 / 0.8$, recall that the ratio of private and public consumption to GDP is 0.8$)$.

- the long-run improvement in the terms of trade of 1 per cent (chart 5). This allows additional consumption of 0.25 per cent (the value of exports is about 25 per cent of that of private and public consumption).

- the improvement in technology, which by 2016 contributes 1.77 per cent to GDP (chart 2). This allows additional consumption of 2.2 per cent $(=1.77 / 0.8)$.

- the increase in the capital stock of 2.26 per cent. Although there is a long-run increase in domestic saving, this is sufficient to finance only a small fraction of the increase in the capital stock. Thus, most of the additional GDP derived from the additional capital stock accrues to foreigners. However, about 25 per cent accrues to the domestic economy through Australian taxes. With returns to capital representing about 40 per cent of GDP, the eCommerce-induced increase in capital allows an increase in private and public consumption in Australia of 0.3 per cent $(=2.26 * 0.4 * 0.25 / 0.8)$.

Up to 2008, the deviation path of investment, as well as consumption, lies above the deviation path of GDP. Consequently, the deviation path of imports must lie above that of exports (chart 5). Beyond 2008, investment weakens as the adjustment in the $\mathrm{K} / \mathrm{L}$ ratio moves towards completion. 
Thus the gap between the import and export deviations narrows. The increase in exports beyond 2008 causes a reduction in the terms of trade (chart 5). However, the deviation in the terms of trade remains positive reflecting the eCommerce-induced movements in foreign demand curves for exports and reductions in the prices of most imports.

The movements in exports and imports are facilitated by movements in the real exchange rate, chart 5. During the early part of the simulation period in which there are large eCommerce-induced deviations in investment, the real exchange rate appreciates. Later, when investment weakens, the real exchange rate declines, thereby allowing an improvement in the real trade balance.

\section{Industry and sector results}

MONASH produces results for 112 industries. In chart 6 , these are aggregated and presented for 18 sectors.

\section{Entertainment (MONASH industries 110-112), rank 1.}

The entertainment sector is ranked first by output in the final year of our simulation. This sector benefits from growth in tourism exports and in consumption. Tourism exports grow strongly relative to other exports mainly because of shock s13. In s13 we stimulate all tourism exports, but only some non-traditional exports (manufacturing) and none of the traditional exports (agriculture and mining).

Transport (MONASH industries 93 - 98), rank 2.

This sector owes its high ranking to Air transport (industry 96). Air transport benefits from tourism demand.

Ownership of dwellings (MONASH industry 104), rank 3.

The output of this sector is the services provided by the housing stock. The housing stock receives a strong boost from eCommerce via the effect of eCommerce on consumption (chart 3).

Construction (MONASH industries 87 - 88), rank 4.

The output deviation in this sector follows closely that of investment (chart 3). Investment increases strongly in the short run to facilitate the adjustment of the economy to a higher $\mathrm{K} / \mathrm{L}$ ratio. Even in the long run, investment is elevated, reflecting the need to maintain a larger capital stock than in the basecase forecast.

Government (MONASH industries 105 - 109), rank 5.

This sector benefits from increased government consumption facilitated by increased overall income. We assume that the percentage deviation in government consumption is half that in private consumption. 
Chart 6. Output by sector (rank in last year)

(\% deviation from basecase forecasts)

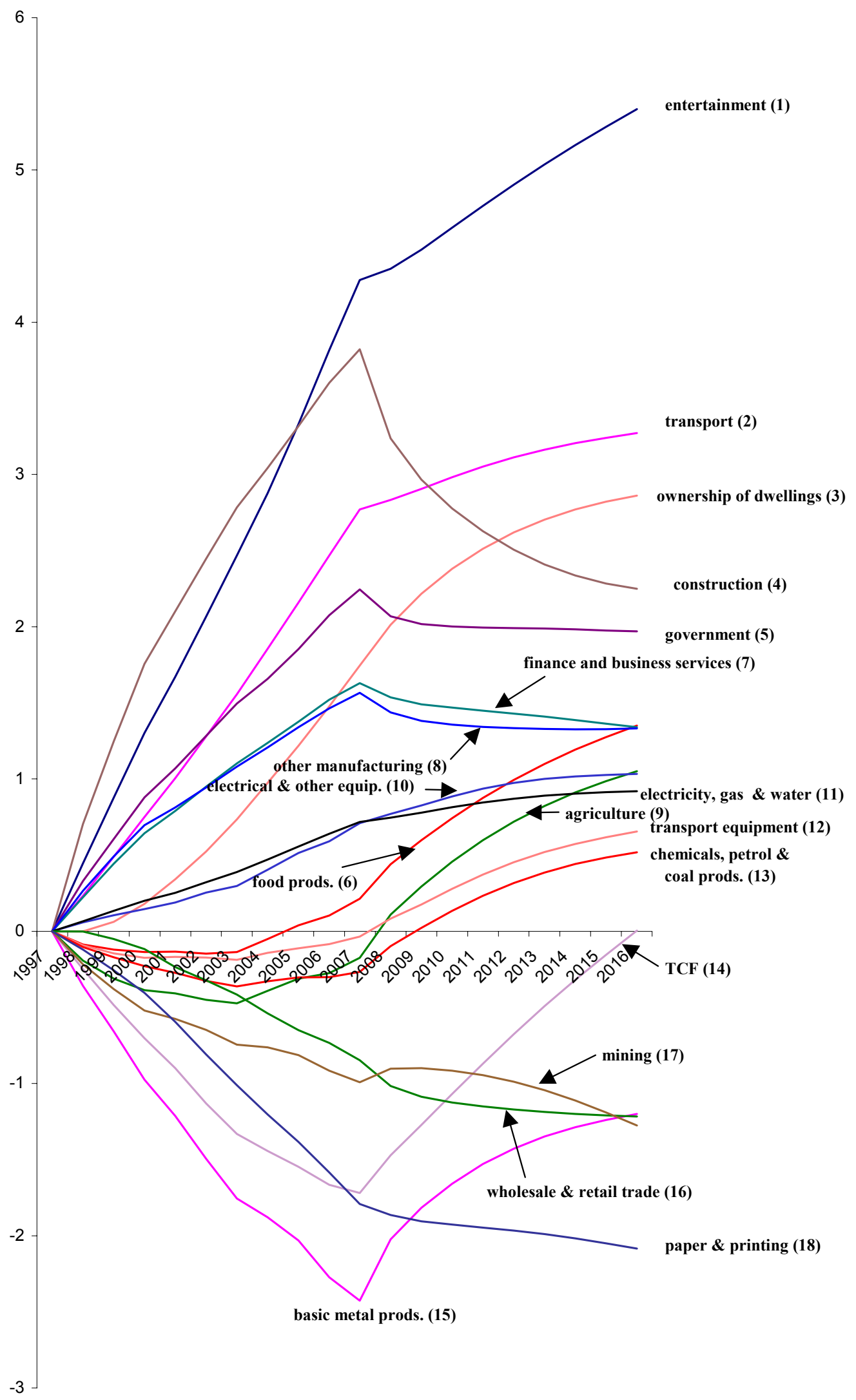


Food products (MONASH industries 18 - 29), rank 6.

This sector is adversely affected in the early part of the simulation period by real appreciation. Later, as the real exchange rate weakens the sector's exports recover. Eventually the sector has a significant positive deviation in output reflecting growth in consumption. Within the sector, standard export commodities (Meat and Sugar) perform poorly. Emerging exports (e.g. Other drinks, mainly wine) perform well via shock s13.

Finance and business services (MONASH industries 99 - 103), rank 7.

This sector achieves major cost reductions via eCommerce. However, expansion of the sector is limited by low price-sensitivities of demand and by the strong link between Business services (industry 103) and Wholesale and retail trade. As discussed below, activity in Wholesale and retail trade contracts under the emergence of eCommerce.

Other manufacturing (MONASH industries 40 - 43, 57 - 62, 79 - 83), rank 8.

This is a diverse group and the average outcome is not informative. Industries 40 to 43 and 57 to 62 consist mainly of materials used in building. The output paths for most of these industries are closely related to that of investment. Industries 80 to 82 (mainly rubber and plastic products) are highly exposed to import competition. They are adversely affected by real appreciation especially in the early years of the simulation. Industries 79 and 83 (leather products and sporting equipment) perform well. They have considerable export potential which is enhanced by shock s13.

Agriculture (MONASH industries 1 - 11), rank9.

Those industries in the sector that produce traditional export commodities (wool, grain and meat) perform poorly relative to those that produce food for the domestic market or inputs (e.g. grapes) used in emerging export products. Traditional exports are harmed by real appreciation.

Electrical and other equipment (MONASH industries 72 - 78), rank 10.

Industries in this sector are influenced by a variety of factors. Industries 76 and 77 (agricultural and construction machinery) benefit from eCommerce via increased foreign awareness of their products. The other industries in the sector benefit from stronger investment and consumption but are harmed by increased competition from imports arising from a stronger real exchange rate.

Electricity, gas and water (MONASH industries 84 - 86), rank 11.

This sector achieves only moderate output deviations. While the outputs of electricity and gas benefit from expansion of consumption, they are damped by the negative deviations of energy-using sectors such as aluminium which are hurt by real appreciation. 
Transport equipment (MONASH industries 68 - 71), rank 12.

This sector is dominated by Motor vehicles (industry 68). Output from the Australian motor vehicle industry is highly sensitive to the real exchange rate. In the early part of the simulation period the industry suffers from import competition brought about by a high real exchange rate. Later when the real exchange rate falls, the industry shows positive output deviations associated with increased activity in the economy.

Chemicals, petrol and coal products (MONASH industries 49 - 56), rank 13.

This sector has a similar output deviation path to that of Transport equipment. The sector contains several exchange-rate-sensitive import-competing industries including Basic chemicals (industry 50), Cosmetics (54), Fertilisers (49) and Explosives (55).

Textiles, clothing and footwear (MONASH industries 30 -39), rank 14.

As with the pervious two sectors, this sector is dominated by exchange-rate-sensitive importcompeting industries.

Basic metal products (MONASH industries 63 - 64), rank 15.

The main industry in this sector is Aluminium (64). eCommerce has no direct beneficial effects on aluminium production. Aluminium output, which is heavily exported, is harmed by increases in real wages (reflected in real appreciation). Real wage increases arise from eCommercerelated productivity gains in the rest of the economy.

Wholesale and retail trade (MONASH industries 89 - 92), rank 16.

The output deviation path for this sector is dominated by the negative result for retail trade (industry 90). Retail trade contracts because of eCommerce-related margin saving (shock s1).

Mining (MONASH industries 12 - 17), rank 17.

As with Basic metal products, this is an export-oriented sector which does not benefit directly from eCommerce but is harmed by higher real wages and real exchange rate.

Paper and printing (MONASH industries 40 - 48), rank 18.

This sector suffers from paper-saving changes in technology brought about by eCommerce (s11). In addition, some industries in the sector, particularly Pulp, paper and paperboard (industry 44), face considerable import competition and are harmed by real appreciation. 


\section{Results for States, Territories and Statistical Divisions}

Chart 7 shows long-run eCommerce-induced deviations for gross state products (GSP) in Australia's six States and two Territories, together with the deviation in real GDP. All States and Territories show gains in output.

The region which is least stimulated is Western Australia. As explained in section 5, eCommerce is likely to reduce activity in mining. Western Australia suffers relative to other regions because of the heavy representation of mining in its economy.

Queensland has a heavy concentration of mining and also export-oriented agriculture. This explains its relatively low ranking in chart 7. An offset for Queensland, which means that it performs better than Western Australia, is its well developed tourism industry.

Like Queensland, Tasmania has over-representations in its economy of traditional exports and of tourism. This gives it a performance under eCommerce similar to that of Queensland. The Northern Territory also has over-representations of traditional exports and of tourism. Its output deviation under the eCommerce shocks is larger than those of Queensland and Tasmania because the Territory, which has a relatively large government sector, benefits from the eCommerce-induced expansion in public expenditure.

Chart 7. GSPs for States and Territories and GDP for Australia in 2016 (\% deviation from basecase forecasts)

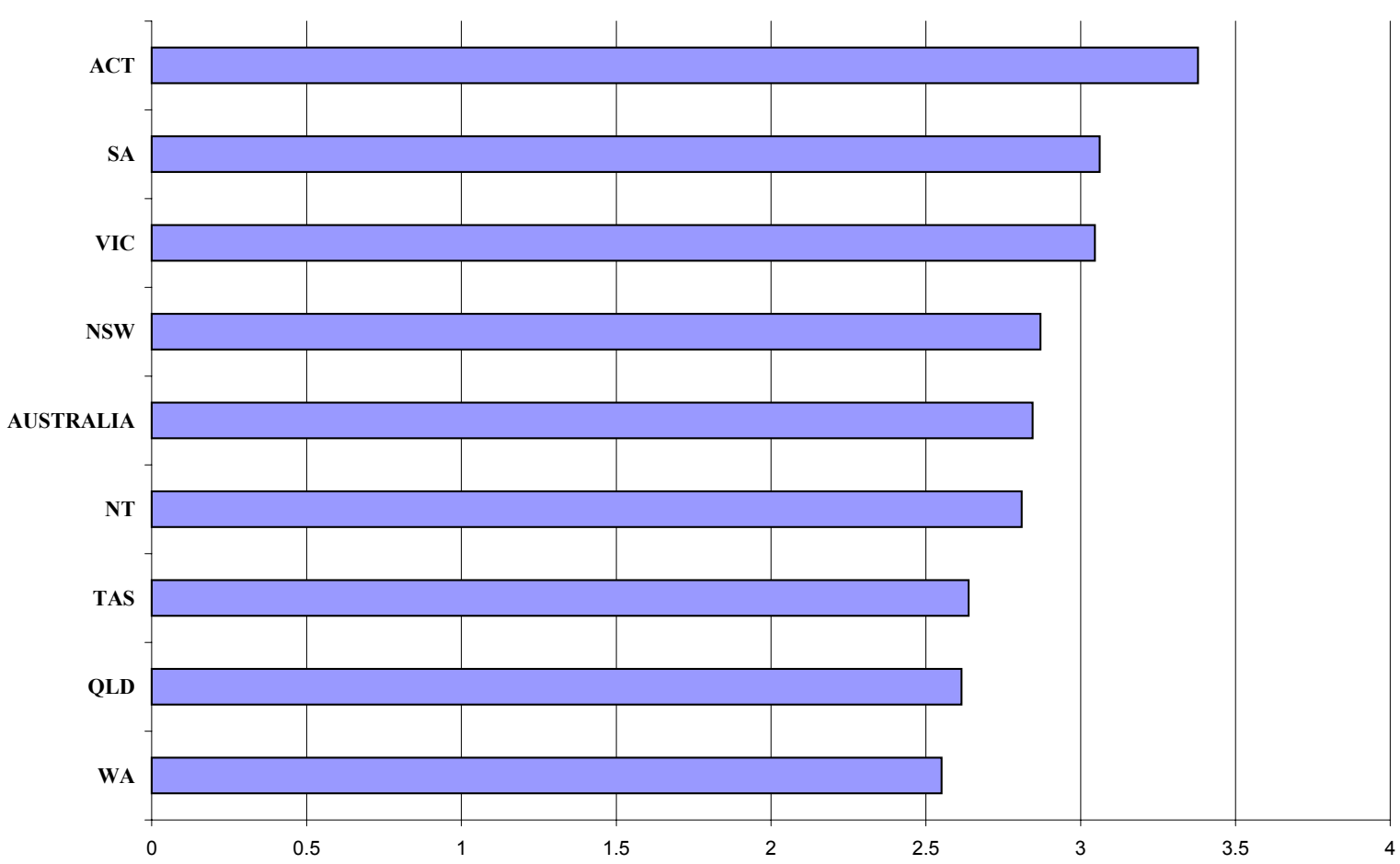


The industrial composition of the New South Wales economy is close to that of Australia. Thus the deviation for GSP in NSW is close to that for Australia's GDP.

Victoria and South Australia have above average prospects under eCommerce because neither state has a heavy reliance on traditional exporting.

The ACT is the region of Australia with least reliance on traditional exporting. This gives it the top ranking in chart 7 .

Chart 8 shows long-run employment deviations for Statistical Divisions. These are relatively uniform, all lying in the range -0.16 to 1.38 per cent. The position of a Statistical Division within this range is determined mainly by the shares of its economic activity accounted for by tourism and traditional exports. The top three Statistical Divisions shown in chart 8, Far North (QLD), Morton (QLD) and Kimberley (WA), all have heavy reliance on tourism. At the other end of chart 8, we find Mackay (QLD), South East (SA), Barwon (VIC), Peel (WA), Far West (NSW), South West (WA), Fitzroy (QLD), North West (QLD) and Goldfields-Esperance (WA). All of these areas rely heavily on either export-oriented agriculture or export-oriented mining, activities which have least to gain from eCommerce.

\section{Results for Occupations}

Charts 9 and 10 show the main winning and losing occupations from the adoption of eCommerce. All of the main winning occupations are associated with hotels, restaurants, entertainment and air travel. These are the industries which will benefit from an eCommerce-related expansion of tourism.

The losing occupations are associated with printing, retailing, ground transport and textiles, clothing and footwear. We identified printing and retailing as losing industries reflecting eCommerce savings of paper (hard copy) and savings of retail margins. Employment in transport is reduced by eCommerce-related labour-saving technical change. The TCF sector is harmed by real appreciation associated with eCommerce-related increases in real wage rates.

\section{The costs of lagging and the benefits of leading}

Officials from NOIE were interested in the effects on our results of slow and fast adoption of eCommerce in Australia relative to the rate of adoption in the rest of the world.

A danger for Australia from lagging behind the rest of the world is loss of market share in tourism and advanced manufactures to competitor countries. In terms of the sets of shocks listed in section 3, Australia would miss out on all or part of s13, in other words Australia would miss the opportunity to increase foreign awareness of Australian products. 
Chart 8. Employment by Statistical Division in 2016 ( $\%$ deviation from basecase forecasts)

34 Far North (QLD)

26 Moreton (QLD)

53 Kimberley (WA)

$13 \mathrm{ACT}$

23 East Gippsland (VIC)

51 Gascoyne (WA)

9 South Eastern (NSW)

52 Pilbara (WA)

4 Richmond-Tweed (NSW)

11 Murray (NSW)

19 Mallee (VIC)

55 Southern (TAS)

39 Murray Lands (SA)

33 Northern (QLD)

37 Outer Adelaide (SA)

22 Ovens-Murray (VIC)

5 Mid-North Coast (NSW)

6 Northern (NSW)

54 Greater Hobart (TAS)

10 Murrumbidgee (NSW)

31 Central West (QLD)

1 Sydney (NSW)

7 North Western (NSW)

17 Central Highlands (VIC)

48 Wheatbelt (WA)

21 Goulbourn (VIC)

24 Gippsland (VIC)

20 Loddon-Campaspe (VIC)

38 Yorke and Lower North (SA)

8 Central West (NSW)

43 Northern Territory

50 Mid West (WA)

56 Northern (TAS)

3 Illawarra (NSW)

41 Eyre (SA)

36 Adelaide (SA)

42 Northern (SA)

18 Wimmera (VIC)

16 Western District (VIC)

29 South West (QLD)

27 Wide Bay - Burnett (QLD)

44 Perth (WA)

2 Hunter (NSW)

28 Darling Downs (QLD)

47 Great Southern (WA)

25 Brisbane (QLD)

57 Mersey-Lyell (TAS)

14 Melbourne (VIC)

32 Mackay (QLD)

40 South East (SA)

15 Barwon (VIC)

45 Peel (WA)

12 Far West (NSW)

46 South West (WA)

30 Fitzroy (QLD)

35 North West (QLD)

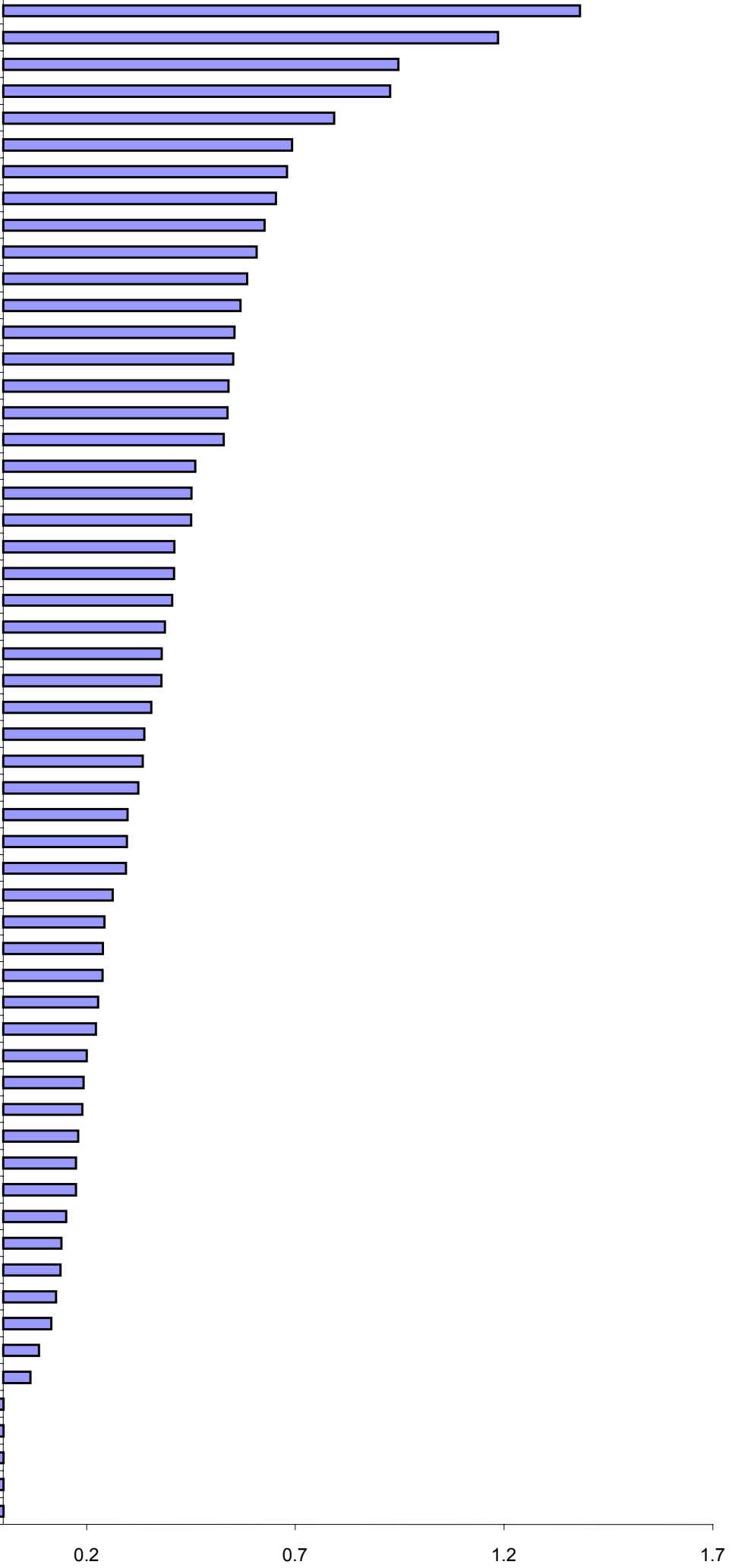


Chart 9. The main winning occupations in 2016

( $\%$ deviation from basecase forecasts)

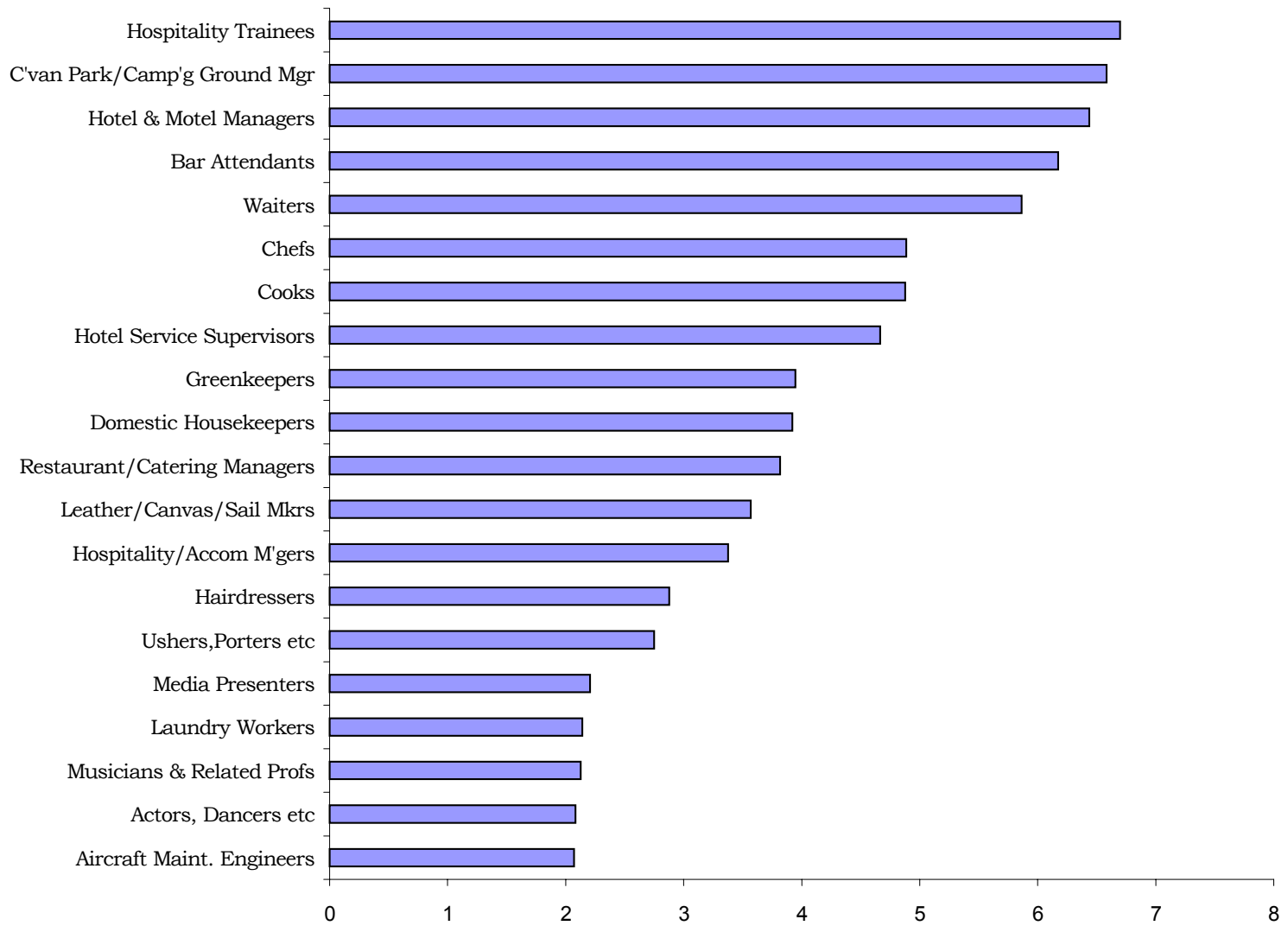

Chart 10. The main losing occupations in 2016

( $\%$ deviation from basecase forecasts)

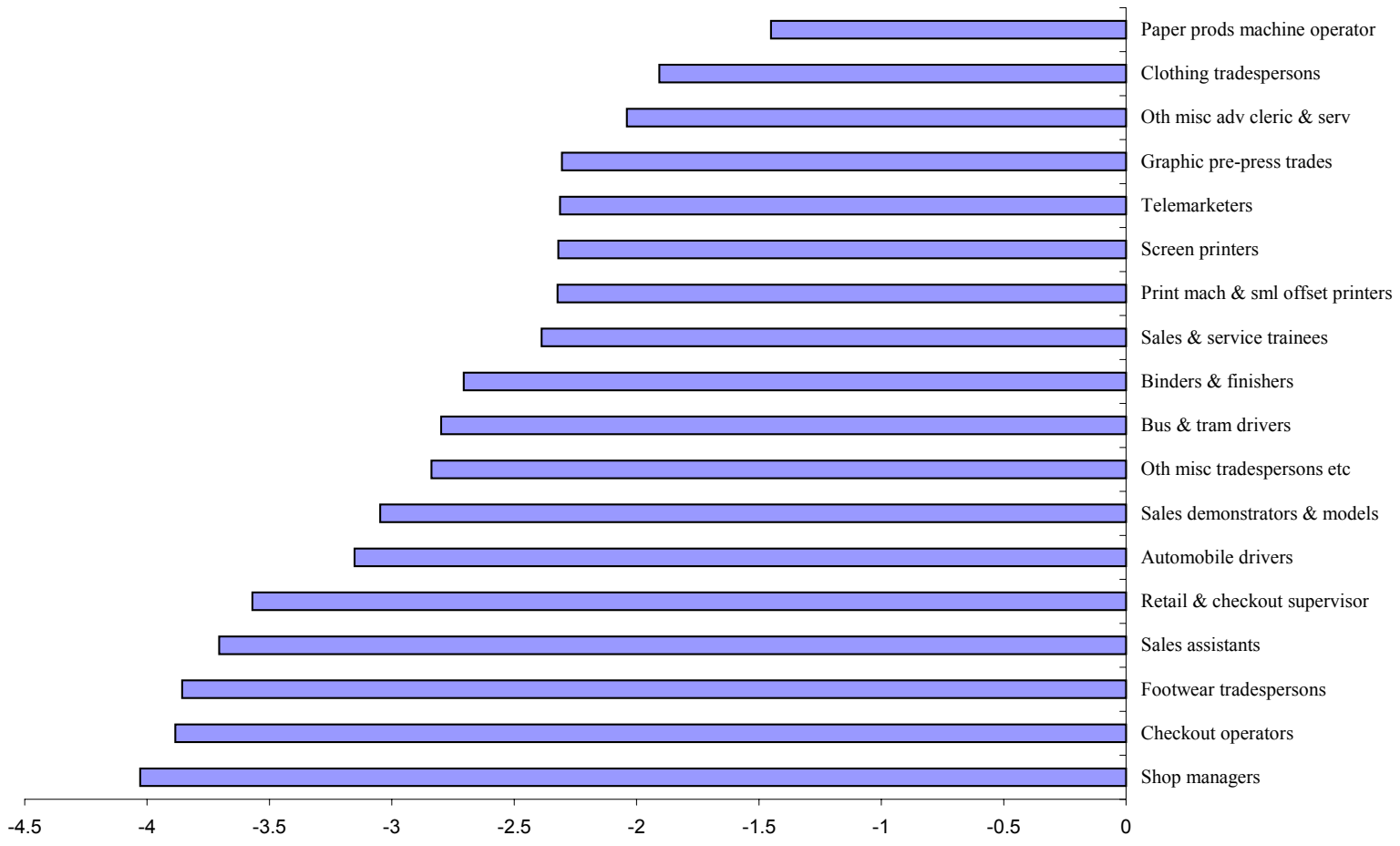


Chart 11 shows the paths of consumption (private and public combined) in three MONASH simulations: the standard simulation of the effects of eCommerce already discussed in the previous sections; a simulation in which Australia lags other countries in adopting eCommerce; and a simulation in which Australia leads other countries. In the lag simulation we assume that Australia increases foreign awareness of its products (s13) at half the rate assumed in the standard simulation, and in the lead simulation we assume that Australia increases foreign awareness of its products at twice the rate assumed in the standard simulation. In the lag simulation we assume that the loss of market share relative to the standard simulation is permanent. That is, after the assumed ten year adoption period, the eCommerce-induced increase in foreign demands for Australian products is permanently left at half the value it had in the standard simulation. Similarly, in the lead simulation we assume that the eCommerce-induced gain in foreign demands for Australian products is permanently left at twice the value it had in the standard simulation.

As could be anticipated from the consumption/welfare effect noted at the end of our discussion of s13 in section 3, the long-run deviation in consumption in the lag simulation is about 0.3 percentage points below that in the standard simulation and the long-run deviation in consumption in the lead simulation is about 0.6 percentage points above that in the standard simulation.

With a discount rate of 5 per cent, the present value of the cost of lagging (the gap between the standard and lag simulation paths in chart 11) is about 6.6 per cent of a year's consumption. The present value of gaining extra market share by leading is about 13.9 per cent of a year's consumption.

Chart 11. Consumption in standard, lead and lag simulations

( $\%$ deviation from basecase forecasts)

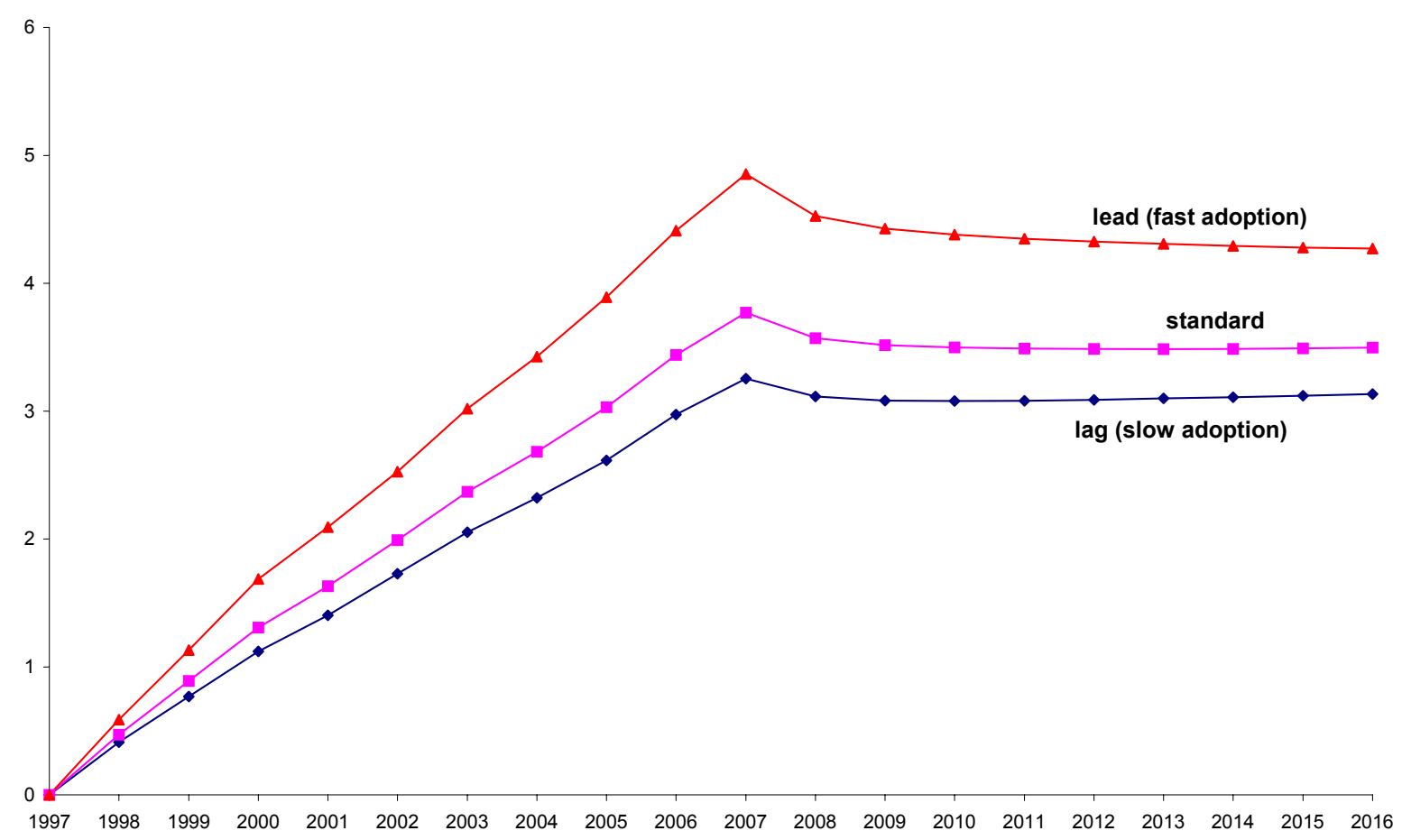




\section{Concluding remarks}

We present two groups of concluding remarks. The first concerns the effects of eCommerce and the second concerns the influence of trade economists on CGE modelling in Australia.

\section{Effects of eCommerce}

In this paper we have represented the direct effects of the adoption of eCommerce as shocks to fourteen sets of technology, preference and trade variables in the MONASH model. The shocks were suggested in discussions with groups of people knowledgeable in the operation of eCommerce and drawn from sectors of the economy most likely to be directly affected by eCommerce. The group discussions produced quantifications of many of the effects identified qualitatively in recent papers by Freebain (2001), Dunt and Harper (2002) and Madden and Coble-Neal (2002).

The main direct effects of eCommerce quantified in the group discussions involve: reductions in the use of retail margins in facilitating the flow of goods and services from producers to households; reductions in the use of wholesale and retail margins in facilitating the flow of goods and services between businesses; improvements in labour efficiency, especially in the finance and transport sectors; increases in the awareness of Australians of some foreign products and similar increases in the awareness of foreigners of some Australian products; reductions in the prices paid by Australians for some foreign products; and saving of shopping time by both businesses and households. We also allowed in our simulations for the creation of an eCommerce industry growing over the next 10 years to an annual level of output of about $\$ 1$ billion (1996/97 prices). This industry will provide equipment, training and software.

In scaling the shocks we attempted to be conservative. Nevertheless, the MONASH simulations show major benefits for the Australian economy. Under our assumptions, eCommerce will, after 10 years, allow a sustained increase in private and public consumption of about 3 per cent. ${ }^{6}$

It is hard to think of changes in the way we do business which have simulated growth dividends as big as that shown for eCommerce. The only example that comes to mind is the Industry Commission's simulation of the Hilmer reforms (Industry Commission, 1995). By adopting a very broad view of the savings which could be attributed to the successful implementation of Hilmer, the Commission found a GDP gain of about 5 per cent. $^{7}$ Other micro-economic reforms such as tariff cuts generate relatively negligible gains. For example, in their final report on the Motor Vehicle Inquiry of

\footnotetext{
${ }^{6}$ Litan and Rivlin (2001) produced a smaller estimate for the US, 1 to 2 per cent. However, as mentioned in footnote 4 , their study stopped with the direct technology effects. It did not include trade-awareness effects or apply an economic model.

${ }^{7}$ Quiggin (1997) argues cogently that the Commission's study exaggerates the benefits of the Hilmer reforms.
} 
1997, the Industry Commission (1997) showed a sustainable consumption gain from the proposed reduction in car tariffs of about 0.3 per cent.

At the micro level, the MONASH results reveal no serious eCommerce-related adjustment problems. The long-run results show that eCommerce will increase the outputs of most sectors. The main exceptions are primary-product exporters and retail trade which are projected to suffer small output losses. eCommerce is not likely to raise foreign awareness of Australia's agricultural and mineral products but it is likely to harm the agricultural and mining industries by strengthening Australia's real exchange rate. Retail trade will be adversely affected by reductions in retail margins per unit of consumer sales. The sectors showing greatest expansion from eCommerce are associated with private consumption (which expands strongly in response to eCommerce-generated increases in real income) and tourism (which benefits from the expansion in domestic consumption and from an upward shift in foreign demand).

Consistent with the sectoral results, MONASH shows eCommerce-generated employment gains in tourism-related occupations such as Hospitality trainee and Hotel manager. Employment losses are shown for retail occupations with the largest being 4 per cent for Shop managers. An employment loss of this size phased in over the period of our simulations does not pose an adjustment problem.

eCommerce will have a relatively uniform stimulatory effect across Australia's States and Territories. The ACT shows the greatest long-run expansion in output (3.4 per cent) and WA the smallest (2.5 per cent). These results largely reflect differences between the two regions in dependence on traditional exports. The ACT also benefits from expansion in public consumption. At the sub-state level, nearly all statistical divisions show eCommerce-induced long-run increases in employment. Employment increases are particularly pronounced in regions specialising in tourism (e.g. Far North Queensland). A few mining and agricultural regions (e.g. Goldfields-Esperance in WA and Fitzroy in Queensland) show small employment losses.

\section{Trade economists and CGE modelling in Australia}

A common criticism of CGE models is that their results are unintelligible. Rauscher (1999) comments that ${ }^{8}$

"To many economists, computable general equilibrium (CGE) models are a bit dubious. They are huge, they are complex, and they appear to be large black boxes that produce results that cannot be traced to an accessibly small set of simple assumptions or axioms."

\footnotetext{
${ }^{8}$ We thank Tony Meagher for drawing our attention to this quotation.
} 
Rauscher then goes on to congratulate the GTAP group (Hertel et al., 1997) on their attempts to interpret CGE results.

In North America, CGE modelling is generally regarded as an outgrowth of the formalisation of the Walrasian system undertaken by Arrow, Debreu and other mathematical theorists in the 1950s and 60s. This was made clear with the award in 1991 by the American Economic Association (AEA) of a distinguished fellowship to Herbert Scarf, a prominent mathematical theorist in the mould of Arrow and Debreu. In part, the fellowship citation read

"Scarf's path-breaking technique for the computation of equilibrium prices has resulted in a new sub-discipline of economics: the study of applied general equilibrium models." [American Economic Review, 82(4), September 1992]. ${ }^{9}$

People working in the Arrow-Debreu-Scarf tradition pay little attention to practical interpretation of results, and for most applied economists the formalisation of the Walrasian system is arcane. Given the central position of North America in economic research, it is then not surprising that CGE models are widely regarded as black boxes.

While CGE modelling in Australia owes much to the United States, ${ }^{10}$ it has developed in a totally different way. The antecedents of Evans (1972) were the multi-sectoral planning models of the 1950s and 60s [e.g. Sandee (1960) and Manne (1963)]. These were formulated and solved as linear and non-linear programming problems. The antecedents of ORANI and MONASH were Johansen's (1960) model of multi-sectoral growth in Norway and Armington's (1969 \& 1970) model of multilateral trade. With these antecedents, the Australian CGE modelling effort has been focused sharply on practical issues, enabling Australian CGE modellers to participate in the ongoing economic policy debate to a greater extent than modellers in other countries. To facilitate their participation, they have developed BOTE models as a way of explaining their results to economists with no particular interest in CGE modelling.

As illustrated in this paper, these BOTE models draw heavily on Australia's tradition of research in international trade and, as required by Rauscher, they have allowed Australian CGE modellers to trace their results "to an accessibly small set of simple assumptions or axioms". Because of the influence of Peter Lloyd and other Australian trade economists, simple trade models are a common language for communication among Australian economists. Thus, the international trade

\footnotetext{
${ }^{9}$ Dixon and Parmenter (1996, pp. 6 \& 7) argue that the AEA misrepresents Scarf's contribution.

10 The major building block in all practical CGE models is an input-output table of the type first formulated by Leontief (1936) at Harvard University. Two of Australia's early CGE modellers, Evans and Dixon, completed their Ph. D.s at Harvard under Leontief's supervision. It is also interesting to note that possibly the two most prominent policy-focused CGE modellers in the US, Dale Jorgenson and Sherman Robinson, also completed their Ph. D.s at Harvard in the 1950s and 60s at the height of Leontief's influence. Both work outside the Arrow-Debreu-Scarf tradition.
} 
tradition in Australian economics has made Australia a fertile ground for CGE modelling. This perhaps explains the pervasiveness of CGE modelling in Australian policy advising.

\section{References}

Armington, Paul S. (1969) "The Geographic Pattern of Trade and the Effects of Price Changes", IMF Staff Papers, XVI, July, 176-199.

Armington, Paul S. (1970) "Adjustment of Trade Balances: Some Experiments with a Model of Trade Among Many Countries", IMF Staff Papers, XVII, November 488-523.

Dixon, P.B. and B.R. Parmenter, "Computable General Equilibrium Modelling for Policy Analysis and Forecasting", Chapter 1, pp.3-85 in H.M. Amman, D.A. Kendrick and J. Rust (eds), Handbook in Computational Economics, Volume 1, Elsevier, Amsterdam, 1996.

Dixon, P.B. and M.T. Rimmer (2002), Dynamic General Equilibrium Modelling for Forecasting and Policy: a Practical Guide and Documentation of MONASH, Contributions to Economic Analysis 256, North-Holland Publishing Company, Amsterdam, pp. xiv+338.

Dixon, P.B. and M.T. Rimmer (1999), "Changes in Indirect Taxes in Australia: A Dynamic General Equilibrium Analysis", Australian Economic Review, 32(4), December, pp.327-348.

Dixon, P.B., B.R. Parmenter, G.J. Ryland and J. Sutton (1977), ORANI, A General Equilibrium Model of the Australian Economy: Current Specification and Illustrations of Use for Policy Analysis, Vol. 2 of the First Progress Report of the IMPACT Project, Australian Government Publishing Service, Canberra, pp.xii +297.

Dixon, P.B., B.R. Parmenter, J. Sutton and D.P. Vincent (1982), ORANI: A Multisectoral Model of the Australian Economy, Contributions to Economic Analysis 142, North-Holland Publishing Company, Amsterdam, pp. xviii +372 .

Dunt, E.S. and I.R. Harper (2002), "E-Commerce and the Australian Economy", The Economic Record, Vol. 78, September, pp.327-342.

Evans, H.D. (1972), A General Equilibrium Analysis of Protection: the Effects of Protection in Australia, Contributions to Economic Analysis 76, North-Holland Publishing Company, Amsterdam, pp. $\mathrm{x}+216$.

Freebain, J. (2001), "Some market effects of e-commerce", Singapore Economic Review, 46(1), pp. 49-62.

Hertel, T.W., editor (1997), Global Trade Analysis: Modeling and Applications, Cambridge University Press, Cambridge, U.K.

Industry Commission (1995), The Growth and Revenue Implications of Hilmer and related reforms: a report by the Industry Commission to the Council of Australian Governments, final report, Australian Government Publishing Service, Canberra, March, pp.581.

Industry Commission (1997), The Automotive Industry, Volumes I and II, Industry Commission Report No. 58, Australian Government Publishing Service, Canberra, May.

Johansen, L. (1960), A Multisectoral Study of Economic Growth, North-Holland, Amsterdam (enlarged edition, 1974).

Klijn, Nico (1974), "Revaluation and Changes in Tariff Protection - The Short Term Effects with Special Reference to Agriculture", paper presented at the Australian Agricultural Economics Society 18th Conference, Perth.

Leontief, W.W. (1936), "Quantitative input-output relations in the economic system of the United States", The Review of Economics and Statistics, 18(3), pp. 105-125.

Litan, R.E. and A.M. Rivlin (2001), "Projecting the economic impact of the internet", American Economic Review, AEA Papers and Proceedings, 91,pp. 313-317. 
Lloyd, P.J. (1978), "Protection Policy", pp. 241-296 in F.H. Gruen, ed., Surveys of Australian Economics, Volume 1, George Allen and Unwin, Sydney.

Madden, G. and G. Coble-Neal (2002), "Internet Economics and Policy: An Australian Perspective", The Economic Record, Vol. 78, September, pp.343-357.

Manne, A.S (1963), "Key sectors of the Mexican economy 1960-1970", in A.S. Manne and H.M. Markowitz, eds, Studies in process analysis, New York: Wiley, pp. 379-400.

National Office for the Information Economy (2000a), E-commerce beyond 2000, Final report, Commonwealth of Australia, Canberra.

National Office for the Information Economy (2000b), E-commerce across Australia, Commonwealth of Australia, Canberra.

National Office for the Information Economy (2001), The Current State of Play 2001, Commonwealth of Australia, Canberra.

Quiggin, J. (1997), "Estimating the benefits of Hilmer and related reforms", Australian Economic Review 30(3), pp. 256-72.

Rauscher, M. (1999), "Review of Global Trade Analysis: Modeling and Applications", Economic Journal, Vol. 109, F799-800.

Sandee, J. (1960), A long-term planning model for India, New York: Asia Publishing House and Calcutta: Statistical Publishing company. 